\title{
Problematika Penentuan Jujuran Di Desa Muara Sumpoi, Kecamatan Murung Kabupaten Murung Raya
}

\author{
Subli \\ Bank BNI Syariah di Kabupaten Murung Raya \\ Sublimr92@gmail.com
}

\begin{abstract}
This research receipts kind of sociological research of Islamic law, or subject using purposive sampling technique that is choosing the subject of research to be the main subject in the data collection in the field. Validating the data of this study using the technique of triangulation that is comparing the observed data with the results of interviews and data analysis techniques is data collection (collecting data), data reduction (Data Reduction), a data display (presentation of data), and data conclousion (conclusion). Of the existing problems, can be obtained a description of the research that determination Problems honesty in the village of Muara Sumpoi due to the factors that influence it, and the more dominant factor is economic. How that is done to resolve the problem of determining the honesty, which gives the sense of religious customs associated with honesty. The way that is done in the view of Islam justified, that honesty should be something that does not contradict the Shari'ah of Islam, because there are no provisions in the governing religion
\end{abstract}

Keywords: honesty, problematic, Murung Kingdom.

\section{A. Pendahuluan}

Islam sebagai agama yang dianut oleh sebagian masyarakat Indonesia memiliki peranan yang sangat penting dalam berbagai aspek kehidupan, semisal dalam kehidupan sosial, politik, ekonomi dan kebudayaan yang masih terjaga dengan baik hingga saat ini, sehingga kadang sulit memisahkan antara kebudayaan asli penduduk setempat dengan kebudayaan yang dibawa dan dikembangkan oleh Islam. ${ }^{1}$ Warga Indonesia sangat variatif dalam suku, agama, ras ataupun golongan, yang kesemuanya itu memiliki ciri khas adat kebiasaan, norma-norma kehidupan, aturan hukum dan kebudayaan yang berbeda antara daerah satu dengan daerah lainnya. Semua itu menyebabkan masyarakat Indonesia mempunyai keanekaragaman tentang upacara adat dalam berbagai hal. Sudah menjadi sunnatullah bahwa Allah SWT menciptakan mahluk hidup secara berpasang-pasangan,

\footnotetext{
${ }^{1}$ Budaya Indonesia yang Beragam," dalam http://www.bimbingan.org/budayaindonesia-yang-beragam.htm, (Online 18 Agustus 2013). 
demikian juga halnya pada manusia selaku makhluk yang tertinggi dan mulia derajatnya. Berbeda dengan makhluk lain, manusia telah diatur oleh syari'at Islam dalam berpasangan, yang diaktualisasikan dalam bentuk pernikahan. Hal ini dimaksudkan supaya manusia dapat hidup secara teratur. Suatu pernikahan tentunya tidak lepas dari adanya motivasi (tujuan) yang mendasarinya, diantaranya adalah untuk dapat hidup bahagia dan rukun dalam rumah tangga hingga akhir hayat dan untuk menjaga kesinambungan kehidupan generasi umat manusia sepanjang masa dalam garis perkembangan yang teratur.

Pemberian jujuran pada masyarakat desa Muara Sumpoi merupakan salah satu langkah awal yang harus dilakukan oleh laki-laki ketika akan melangsungkan perkawinan yang ditentukan setelah adanya proses lamaran. Adanya pemberian jujuran dalam suatu perkawinan, menjadikan hal tersebut sebagai syarat guna mencapai suatu tujuan, yaitu pernikahan yang ideal dalam suatu masyarakat adat. Jujuran memegang suatu peranan penting di dalam masyarakat Desa Muara Sumpoi terkait dengan perkawinan adat, karena adanya suatu kewajiban dalam hal pemenuhan jujuran yang dibebankan kepada calon suami. Pemberian jujuran dalam adat perkawinan dapat diberikan terlebih dahulu pada saat prosesi pernikahan, Jika lamaran telah diterima maka tahap selanjutnya adalah penentuan jujuran yang jumlahnya ditentukan terlebih dahulu oleh pihak wanita yang dilamar dan jika pihak laki-laki menyanggupi maka tahap perkawinan selanjutnya bisa segera di dilangsungkan.

Walaupun terkadang terjadi tawar-menawar sebelum tercapainya kesepakatan jika pihak laki-laki keberatan dengan nominal jujuran yang dipatok. Adapun akibat hukum jika pihak laki-laki tidak mampu menyanggupi jumlah jujuran yang di targetkan, maka secara otomatis perkawinan akan batal dan pada umumnya implikasi yang muncul adalah pihak keluarga laki-laki dan perempuan akan mendapat cibiran atau hinaan di kalangan masyarakat setempat. 
Secara tekstual tidak ada peraturan yang mewajibkan tentang pemberian uang jujuran sebagai syarat sah perkawinan. Pemberian wajib ketika akan melangsungkan sebuah perkawinan dalam hukum Islam hanyalah mahar dan bukan jujuran. Sebagaimana yang telah disebutkan dalam firman Allah surah an-Nisa ayat 4 :

Terjemahan : Berikanlah maskawin (mahar) kepada wanita (yang kamu nikahi) sebagai pemberian dengan penuh kerelaan. Kemudian jika mereka menyerahkan kepada kamu sebagian dari maskawin itu dengan senang hati, Maka makanlah (ambillah) pemberian itu (sebagai makanan) yang sedap lagi baik akibatnya.

Pada masyarakat desa Muara Sumpoi kecamatan Murung Kabupaten Murung Raya, sebagian masyarakatnya menganggap jujuran adalah pemberian calon suami kepada calon istri, bukan hanya kewajiban. Tetapi merupakan pemberian jujurannya harus maksimal dan sesuai keinginan pihak calon istri. Hal inlah yang menyebabkan praktik pemberian jujuran dalam adat perkawinan cenderung terkesan memberatkan pihak calon suami, karena tidak jarang yang terjadi di masyarakat bahwa, harta jujuran tersebut dari segi nilai dan bentuknya sangat besar dan sult untuk dipahami. Hal-hal tersebut tentunya akan menimbulkan berbagai persepsi di kalangan masyarakat, terutama bagi calon suami yang tidak mempunyai kadar jujuran yang maksimal atau materi, tentunya hal tersebut akan menjadi permasalahan baginya, padahal Islam tidak mempersulit umatnya termasuk dalam masalah mahar.

Berdasarkan latar belakang tersebut di atas, penulis merasa tertarik untuk meneliti permasalahan tentang problematika penentuan jujuran yang terjadi di Desa Muara Sumpoi, Kecamatan Murung, Kabupaten Murung Raya. Ketertarikan penulis terhadap permasalahan di atas diaktualisasikan dalam bentuk karya ilmiah yang berjudul: "Problematika Penentuan Jujuran di Desa Muara Sumpoi, Kecamatan Murung, Kabupaten Murung Raya (Studi pada 3 Calon Pasangan)”. 


\section{B. Kajian Pustaka}

Untuk memperjelas wilayah penelitian ini, maka penting bagi penulis untuk mengkaji terlebih dahulu penelitian-penelitian yang sama yang sudah ada sebelumnya. Di mana setelah melakukan beberapa kajian, dapat disimpulkan bahwa perhatian para peneliti terhadap masalah-masalah yang berkaitan dengan mahar dan jujuran terbilang cukup besar, hal itu terlihat dari sekian hasil penelitian yang ada. Penelitian tersebut adalah Sebagai berikut:

Skripsi dari Nurin Najmi, mahasiswi STAIN Palangka Raya Tahun 2003, dengan judul "Persepsi Masyarakat Banjar Terhadap Mahar dan Jujuran dalam Perkawinan di Kecamatan Martapura Kabupaten Banjar Kalimantan Selatan (Studi Terhadap 10 orang warga Martapura)”. Fokus permasalahan dalam skripsi ini mengenai persepsi dan latar belakang persepsi masyarakat masyarakat Banjar terhdap mahar dan jujuran dalam perkawinan di Kecamatan Martapura, Kabupaten Banjar, Kalimantan Selatan. Hasil penelitian menunjukan bahwa dari sepuluh orang responden terdapat tujuh orang yang menyatakan bahwa mahar itu sama dengan jujuran karena sama-sama syarat yang harus dipenuhi oleh calon mempelai laki- laki kepada calon mempelai perempuan yang akan dikawininya, sedangkan tiga orang menyatakan bahwa mahar itu berbeda dengan jujuran karena mahar adalah pemberian wajib yang telah diatur oleh Allah SWT. Latar belakang persepsi masyarakat Banjar menyamakan mahar dan jujuran karena keduanya memiliki maksud yang sama sebagai pemberian, berbentuk barang atau uang diberikan untuk calon mempelai perempuan. Skripsi dari Dina Aprilia, mahasisiwi IAIN Wali Songo Semarang telah melakukan penelitan pada tahun 2007 dengan judul "Budaya Jujuran dalam Perkawinan Adat Banjar". Fokus penelitian ini membahas tentang budaya jujuran perkawinan adat Banjar ditinjau dari pandangan pria suku Banjar sebagai pihak yang dibebankan untuk memberikan jujuran sebagai mahar kepada pihak wanita. Hasil penelitian 
didapatkan bahwa, persepsi pria suku Banjar terhadap budaya jujuran dalam perkawinan adat adalah merupakan kewajiban pria suku Banjar yang harus dijalankan dalam perkawinan, budaya yang sudah turun temurun,dan merupakan kebanggaan apabila dijalankan dalam perkawinannya. Dampak sosial yang diterima pria suku Banjar adalah penilaian positif yang berupa pujian dan penilaian negatif yang berupa sindiran yang datang dari masyarakat, sedangkan dampak psikologis adalah perasaan senang karena terhindar dari penilaian negatif dari masyarakat.

\section{Metode Penelitian}

Penelitian hukum yang akan dilakukan ini adalah tipe atau jenis penelitian sosiologi hukum Islam, hal itu didasarkan kepada pendapat Amir Mu'allim dan Yusdani, bahwa yang dimaksud dengan pendekatan sosiologi hukum Islam adalah,"mempelajari faktor-faktor sosial, politik, dan kultural yang melatarbelakangi lahirnya suatu produk pemikiran fikih dan bagaimana dampak produk pemikiran fikih itu terhadap masyarakat". 2 Penelitian lapangan (field reseach) yang dilakukan ini di mana semua data, akan diperoleh dari lapangan. Dalam penelitian ini melakukan suatu studi law in action, karena mempelajari dan meneliti hubungan timbal balik antara hukum dengan lembaga-lembaga sosial lain. Hukum secara empiris merupakan gejala masyarakat, disatu pihak dapat dipelajari sebagai suatu variabel penyebab (independent variable) yang menimbulkan akibatakibat pada berbagai segi kehidupan sosial. ${ }^{3}$

Konsep dasar dari penelitian hukum ini tidaklah mengadakan perhitungan sebagaimana penelitian kuantitatif yang mana melibatkan dari pada perhitungan angka ataupun kuantitas. Untuk mengetahui lebih lanjut tetang dasar-dasar kualitatif yang dipakai dalam penelitian hukum ini, maka pendapat Begdan dan Taylor (1975:5) dan Kirk dan Miler (1986:9) dalam Moleong mengatakan sebagai berikut berikut:

${ }^{2}$ Amir Mu'allim dan Yusdani, Konfigurasi Pemikiran Hukum Islam, Yogyakarta: UII PressIndonesia, 2001, h. 128.

${ }^{3}$ Ronny Hanitijo Soemitro, Metodologi Penelitian Hukum dan Jurinetri, Jakarta : Ghalia Indonesia, Cet ke- 4, 1990, h.34. 
Untuk mengadakan pengkajian selanjutnya terhadap istilah penelitian kualitatif perlu kiranya ditemukan beberapa definisi. Pertama, Bogdan dan Taylor (1975:5) mendefinisikan "metode kualitatif" sebagai prosedur penelitian yang menghasilkan data deskriptif berupa kata- kata tertulis atau lisan dari orang-orang dan perilaku yang dapat diamati. Menurut mereka, pendekatan ini diarahkan pada latar dan individu atau organisasi ke dalam variabel atau hipotesis, tetapi perlu memandangnya sebagai bagian dari suatu keutuhan. Sejalan dengan definisi tersebut, Kirk dan Miler (1986:9) mendefinisikan bahwa penelitian kualitatif adalah teradisi tertentu dalam ilmu pengetahuan sosial yang secara fundamental bergantung pada pengamatan pada manusia dalam kawasannya sendiri dan berhubungan dengan orang-orang tersebut dalam bahasanya dan dalam peristilahanya. ${ }^{4}$

Dalam penelitian ini penulis meneliti mengenai Problematika penentuan jujuran di desa Muara Sumpoi Kecamatan Murung Kabupaten Murung Raya. Adapun tujuan dari penelitian ini adalah sebagai berikut: Untuk mengetahui Faktor yang menjadi problematika dalam penentuan jujuran di Desa Muara Sumpoi, Kecamatan Murung, Kabupaten Murung Raya. Untuk mengetahui cara pihak calon pasangan menyelesaikan Problematika penentuan jujuran. Untuk mengetahui pandangan hukum Islam terhadap cara yang dilakukan pihak calon pasangan dalam menyelesaikan problematika penentuan jujuran.

\section{Pembahasan}

Faktor yang Menjadi Problematika dalam Penentuan jujuran

di Desa Muara Sumpoi. Pemberian jujuran pada masyarakat desa Muara Sumpoi merupakan salah satu langkah awal yang dilakukan oleh laki-laki ketika akan melangsungkan perkawinan yang ditentukan setelah adanya proses lamaran. Jika lamaran telah diterima maka tahap selanjutnya adalah penentuan jujuran yang jumlahnya ditentukan terlebih dahulu oleh pihak wanita yang dilamar dan jika pihak laki-laki menyanggupi maka tahap perkawinan selanjutnya bisa segera di dilangsungkan. Walaupun terkadang terjadi tawar-menawar sebelum tercapainya kesepakatan jika pihak laki-

${ }^{4}$ Sabian Utsman, Dasar-dasar Sosiologi Hukum, Yogyakarta: Pustaka Pelajar, 2009, h.382-383. 
laki keberatan dengan jumlah jujuran yang dipatok. Pada masyarakat yang tingkat pendidikannya rendah tetapi taraf kesejahteraan hidupnya sudah lebih dari cukup, kebanyakan dari mereka tidak mempermasalahkan besar kecilnya jujuran yang akan diterima oleh anaknya, bagi mereka yang lebih penting adalah tradisi tersebut tetap dilaksanakan, bukan besar kecilnya jujuran.

Sedangkan pada masyarakat yang tingkat pendidikannya rendah dan taraf kehidupannya pas-pasan, masalah penentuan jujuran sering dijadikan sarana untuk mendapat sesuatu yang lebih. Semisal dengan meminta jujuran dengan nominal yang cukup besar, karena pihak perempuan memang mempunyai hak untuk mengajukan permintaan tentang jumlah jujuran yang nantinya akan diterima, dan jujuran sering dijadikan sebagai hal yang berorientasi pada keuntungan. Hal tersebut tidak berarti bahwa yang meminta jujuran dengan jumlah banyak hanyalah dari masyarakat yang taraf kehidupannya pas-pasan.

Problematika yang di alami oleh pasangan LT dan JR, LL dan AR, dan pasangan AS dan SW, menggambarkan kesedihan seorang pasangan yang tak jadi menikah dengan pasangan yang mereka pilih hanya dikarenakan harus memenuhi persyaratan yang dikenal sebagai Jujuran yang kini sudah mulai berubah dan disalahartikan. Tak mampu memenuhi sejumlah permintaan yang diminta oleh orangtua mempelai perempuan. Status sebagai seorang yang memiliki pekerjan (tidak menganggur) tidak cukup bagi orangtua perempuan untuk menerima laki-laki untuk menjadi suami bagi anaknya. Bagi orangtua perempuan jujuran merupakan syarat yang harus dipenuhi dalam pernikahan adat Suku Bakumpai dan tidak bisa dihilangkan karena menjadi bagian dari persyaratan. Jujuran dalam adat pernikahan masyarakat Bakumpai merupakan salah satu tradisi. Jujuran merupakan pemberian dari pihak mempelai laki- laki kepada pihak perempuan dalam bentuk sejumlah uang. Banyak yang salah mengartikan jujuran sama dengan mahar. Jujuran berbeda dengan mahar dan seserahan 
(barang). Jujuran bukan hak milik sepenuhnya untuk mempelai wanita seperti halnya mahar, karena uang jujuran dapat digunakan untuk membiayai pesta pernikahan dan dapat digunakan oleh orangtua mempelai perempuan untuk membeli kebutuhan perempuan serta sebagai modal awal untuk membangun rumah tangga. Besaran nilai jujuran tergantung oleh beberapa hal seperti latar belakang mempelai perempuan. Semakin terpandang dan terhormat keluarga mempelai wanita maka semakin tinggi nilai jujuran-nya. Selain itu jujuran juga ditentukan tingkat kecantikan mempelai wanita, semakin cantik paras wanita semakin tinggi pula nilai jujuran. Saat ini faktor yang juga memengaruhi nilai jujuran adalah kemeriahan acara resepsi pernikahan, yang mana acara tersebut membutuhkan biaya yang cukup besar, maka nilai jujuran makin tinggi pula. Seharusnya para orang tua mengerti dengan benar maksud diwajibkannya membayar jujuran, niscaya mereka tidak akan meminta persyaratan-persyaratan yang memberatkan yang tidak ada keterangan dan penjelasan dari agama. Misalnya meminta biaya persiapan pesta pernikahan, baju pengantin, bekal memasuki rumah tangga, juga termasuk jumlah nominal jujuran. Dengan cara demikian, berarti mereka telah menjerat dan mencekik leher pemuda-pemuda yang berasal dari keluarga yang tidak mampu. Namun saat ini tradisi jujuran menuai pro-kontra. Sebagian masyarakat setuju untuk mempertahankan tradisi jujuran, namun ada sebagian masyarakat yang mulai kritis terhadap tradisi yang sudah bertahan dan merupakan warisan nenek moyang. Masyarakat yang pro menganggap jujuran merupakan bagian tradisi yang sudah seharusnya dipertahankan dan dilestarikan. Sedangkan responden AR dan SW yang kontra menganggap tradisi ini memberatkan bagi mempelai pria, terlebih lagi besaran nilai jujuran yang ditentukan oleh faktor-faktor tertentu yang sebenarnya tidak esensial. responden LT, Ll dan SW, juga menolak tradisi ini karena beranggapan bahwa tradisi jujuran tidak terdapat dalam hukum (syariat) agama Islam. Di mana agama Islam hanya mensyaratkan mahar 
sebagai syarat pernikahan. Penulis menganggap tradisi jujuran memang tidak sesuai dengan syariat Islam, karena tidak ada ayat maupun hadis yang membenarkan adanya pemberian selain mahar terlebih lagi karena faktor tertentu. Pernikahan tidak boleh memberatkan, karena pada hakikatnya pernikahan adalah sebuah bentuk ibadah dan ibadah tidak akan pernah memberatkan. Selain itu ada beberapa pengaruh negatif yang didapatkan dari pengalaman rumah tangga yang menuntut jujuran yang tinggi, diantaranya: ${ }^{5}$ Pernikahan yang menuntut jujuran memberikan kesan masyarakat yang memiliki kasta-kasta. Biasanya pernikahan dilakukan oleh pihak-pihak yang memiliki tingkat yang setara. Pihak wanita lebih memilih calon dari pihak yang setara karena berharap pihak pri diharapkan mampu memenuhi nilai yang diajukan oleh pihak wanita. Tidak memberikan jaminan pria yang mampu memnuhi jujuran-nya dapat menjadi kepala rumahtangga yang baik. Ada kalanya calon mempelai pria yang berasal dari golongan menengah keatas tidak memiliki kemampuan untuk mandiri. Mempelai pria dari golongan menengah keatas beberapa di antaranya selalu di manjakan oleh orangtuanya sehingga cenderung diantara mereka tidak memiliki pekerjaan dan apabila memiliki pun merupakan usaha warisan orantuanya. Banyak kasus terjadi ket ika usaha kedua orangtuanya bangkrut (akibat ketidakmampuan mengelola usaha keluarga), anak tidak mampu bangkit dan mandiri membangun usahanya kembali. Tidak menjamin keluarga yang harmonis. Pernikahan yang tidak dilakukan atas dasar saling mencintai dan proses perkenalan yang kurang membuat rumahtangga rawan konflik bahkan dapat memicu timbulnya Kekerasan Dalam Rumah Tangga (KDRT). Masing-masing tidak mengenali pribadi masing-masing; Memberikan citra negatif bagi masyarakat Bakumpai itu sendiri mengingat masyarakat yang mayoritas beragama Islam namun tidak menerapkan syariat Islam. Masyarakat justru menerapkan tradisi yang tidak terdapt landasan

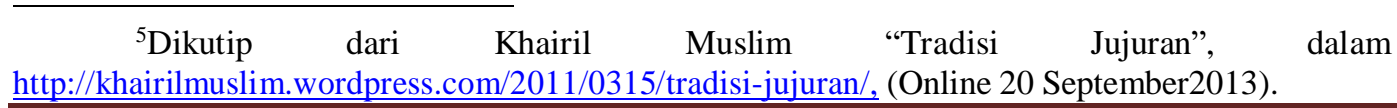


syariatnya. Penulis mengkritisi sikap orangtua yang "mematok" nilai jujuran putrinya. Seolah-olah orangtua menetapkan harga tertentu untuk menikahkan putrinya. Selain itu orangtua hanya melihat calon menantunya hanya dari keadaan sekarang bukan melihat potensi dan prospek masa depan menantunya. Seperti yang dialami calon pasangan LT dan JR, LL dan AR dimana orangtua dari calon mempelai wanita tidak mengapresiasi pekerjaan calon pria. Meskipun AR dan SW hanya berstatus sebagai pekebun karet, paling tidak pria tersebut memiliki pekerjaan dari hasil jerih payahnya sendiri. Orangtua dari calon mempelai wanita yaitu TI, BK dan MR tidak memilik pemahaman bahwa dengan hidup di awal masamasa berumah tangga memang membutuhkan pengorbanan. Di mana masamasa itu baik untuk membentuk karakter keluarga yang kuat di masa depan. Melihat problematika yang di hadapi oleh calon pasangan, LT, LL, dan AS, yang ingin melangsungkan pernikahan sedangkan untuk keberlangsungan perkawinan mereka tidak mendapat dukungan dari keluarga padahal dukungan keluarga sangatlah penting dalam berlangsungnya pernikahan,tanpa dukungan keluarga perkawinan tidak dapat terlaksana. Dukungan keluarga menyangkut tentang wali, dengan adanya wali dapat melaksanakan akad nikah.

Melihat tujuan mereka untuk menikah, dan memperhatikan uraian Imam Al-Ghazali dalam Ihyanya tentang faidah melangsungkan perkawinan, maka tujuan perkawinan dapat dikembangkan menjadi lima yaitu : Mendapatkan dan melangsungkan keturunan; Memenuhi hajat manusia untuk menyalurkan syahwatnya dan menumpahkan kasih sayang; Menumbuhkan kesungguhan untuk bertanggung jawab menerima hak dan kewajiban; Memenuhi panggilan agama, memelihara diri dari perbuatan kejahatan dan kerusakan; Membangun rumah tangga untuk membentuk masyarakat yang tentram atas dasar cinta dan kasih sayang. ${ }^{6}$

${ }^{6}$ Abdul Rahman Ghozali, Fiqh Munakahat, Jakarta: Kencana, 2008, h. 24. 
Melihat tujuan pernikahan di atas, seharusnya masalah materi adalah suatu hal yang biasa terjadi pada setiap manusia, padahal dalam membina rumah tangga tidak perlu dilihat dari segi materinya tetapi lebih memahami permasalahan agama, tujuan pernikahan, syarat dan rukun sahnya pernikahan dan syari'at Islam. Pada Pasal 2 UUP disebutkan:

"Perkawinan adalah sah apabila dilakukan menurut hukum agamanya masing-masing dan kepercayaan."7

Berdasarkan Undang-undang tersebut di atas, sahnya pernikahan menurut UUP ialah dilakukan sesama agama dan kepercayaan bukan organisasi, karena dengan melakukan perkawinan, ikatan batin antara keluarga akan terasa lebih erat. Problematika yang di hadapi oleh calon pasangan, LT, LL, dan AS, apabila dilihat dalam ushul fiqh berdasarkan pandangan syar'i untuk menjaga maqasłhid al-syari'ah, para ulama menggolongkan maslahah menjadi Tiga tingkatan: Maslahah Dhoruriyyat yaitu maslahah yang ditetapkan demi keberlangsungan hidup manusia di dunia maupun diakherat; Maslahah Hajiyyat yaitu maslahah yang dibutuhkan oleh manusia hanya untuk menghilangkan kesulitan pada dirinya; Maslahah Tahsiniyyat yaitu maslahah yang dimaksudkan untuk memperbaiki adat kebiasaan dan memuliakan akhlak manusia. Hukumhukum yang mengandung kemashlahatan Tahsiniyyat menjadi lebih penting untuk didahulukan dan dijaga. Melihat permasalahan di atas dapat disimpulkan bahwa maslahah yang mengandung unsur kebaikan tetap dipertahankan dan lebih memahami permasalahan agama bukan memahami dari segi materi karena materi bukanlah sesuatu yang tidak dibolehkan dalam menjalin hubungan apalagi dalam menjalin perintah Allah yang menganjurkan seseorang untuk menikah. Sudah saatnya meluruskan pemahaman bahwa perjodohan bukanlah masalah materi. Pernikahan merupakan sebuah rangkaian proses pembelajaran kehidupan. Menurut penulis pernikahan membawa nilai ibadah karena ada proses pembelajaran

${ }^{7}$ Kaelany, Aspek-aspek kemasyarakatan, Jakarta: Bumi Aksara, 2000, h. 139 
di dalamnya dalam rangka pembentukan insan yang memiliki karakter dan tentu saja menebalkan keimanan dan ketakwaan kepada Allah SWT.

Salah satu dari tujuan dari sebuah pernikahan ialah terbentuknya keluarga sakinah, untuk menciptakan keluarga sakinah tersebut tidak lepas dengan adanya hak-hak dan kewajiban suami-istri. Setiap permasalahanpasti akan ada penyelesaiannya. Islam memberikan ramburambu dalam sejumlah ayat Alquran sebagai pedoman yang dapat digunakan untuk pegangan bagi calon pasangan dalam upaya membangun dan melestraikanya. Akan tetapi pada realita yang ada tidak semua orang faham tentang hal tersebut. Mereka mempunyai cara sendiri-sendiri dalam menyelesaikan permasalahan, namun upaya mereka tidak jauh beda dengan apa yang sudah terkonsep dalam Alquran. Misalanya calon pasangan LL dan AR menyelesaiakan permasalahan yang dialaminya mempertahankan keutuhan hubungannya berusaha bersabar, bersifat jujur dan memahami keadaan lingkungan keluarga meskipun sudah berpikir untuk kawin lari.

Cara penyelesaian seperti ini juga dilakukan oleh calon pasangan AS dan SW, cara mereka menyelesaikan permasalahan dalam pernikahan mereka bersikap lebih bersabar menghadapi orang tua dengan cara pendekatan diri yang dilakukan SW terhadap orang tua AS, agar lebih mengenal dan memahami kehendak orang tua meskipun bertentangan dengan keinginan mereka dan tidak ada pilihan lain selain berusaha meyakinkan orang tua. Berbeda dengan calon pasangan LL dan AR, LT dan JR upaya menyelesaikan permasalahan dalam keluarga mereka berusaha untuk saling memberi pengertian keagamaan yang berkaitan dengan adat jujuran kepada orang tua LT. Kedua calon pasangan ini mempunyai pemikiran yang berbeda akan tetapi upaya mereka dalam menyelesaikan permasalahan keluarga merupakan faktor pendukung terlaksananya perkawinan dibanding memikirkan kehendak sendiri. Menggunakan cara yang berbeda, namun saling melengkapi dengan demikian mereka berharap akan terlaksananya perkawinan yang selama 
ini mereka impikan. Menurut penulis melihat permasalahan yang dihadapi calon pasangan dalam menyelesaikan problematika penentuan jujuran tersebut, Sikap materialistis ini seharusnya tidak membuat orang tua tertutup dengan pandangan yang berbeda Walau tidak semua individu dari masyarakat bertujuan ingin mendapatkan jujuran yang besar dalam sebuah pernikahan. Dengan d diterimanya jujuran dengan jumlah yang cukup besar, akan dapat menjadi sebuah kebanggaan (prestise) tersendiri bagi orang tua pihak wanita dan dari pihak laki-laki-pun akan turut merasa bangga karena mampu memberikan jujuran dengan nominal tinnggi. Bila pihak laki-laki merasa keberatan dengan jumlah jujuran yang diajukan pihak perempuan, maka masalah besar-kecilnya jujuran dapatlah diselesaikan secara kekeluargaan dengan (musyawarah) dan saling menyatukan kesepakatan yang tentunya bertujuan agar tidak mengecewakan kedua belah pihak. Sebagaimana konsep kafa'ah, dalam hukum Islam tidak diatur secara spesifik baik dalam Alquran maupun dalam hadis Nabi, namun para ulama sepakat menempatkan tingkat ketaatan agama sebagai kriteria kafa'ah'. Kafa'ah dalam perkawinan bukan merupakan syarat, tetapi hanya sebuah keutamaan saja. Sehingga permasalahan kafa'ah ini tidak menjadi penghalang perkawinan. Berdasarkan konsep kafa'ah dalam hukum Islam yang hanya berupa sebuah keutamaan, maka seharusnya penentuan jujuran ini bukan menjadi penghalang dalam pelaksanaan perkawinan. ${ }^{10}$

Menurut UUP RI NO. 1 tahun 1974 :

"Perkawinan ialah ikatan lahir batin antara seseorang pria dan wanita sebagai suami istri dengan tujuan membentuk keluarga yang bahagia dan kekal brdasarkan ketuhanan yang maha esa." "l1

Pada Pasal 2 UUP disebutkan:

\footnotetext{
${ }^{8}$ Salim Suharis, “Jujuran, Budaya Pernikahan Yang Kurang Islami”, dalam http//salim suhari-jujuran-budaya-islam.net, (Online 1 September 2013).

${ }^{9}$ Abdul Rahman Ghozali, Fikih Munakahat, h. 96-101.

${ }^{10}$ Ibid

${ }^{11}$ Kaelany, Aspek-aspek kemasyarakatan, Jakarta: Bumi Aksara, 2000, Ed. 2. Cet. 1. h. 139.
} 
"Perkawinan adalah sah apabila dilakukan menurut hukum agamanya masing-masing dan kepercayaan."12

Melihat dari pandangn hukum Islam, UUD No 1 tahun 1974 tentang sikap agama Islam terhadap perkawinan, masyarakat Desa Muara Sumpoi seharusnya dalam proses awal menuju jenjang pernikahan tidak hanya memandang atau menilai seseorang dari segi materi, tetapi harus menilai dari status sosial, pendidikan, akhlaq dan kepribadiannya. dilihat dari dipenuhinya semua rukun nikah, syarat-syarat nikah, dan tidak melanggar larangan perkawinan sebagaimana yang ditentukan syari'ah. Secara tekstual tidak ada peraturan yang mewajibkan tentang pemberian jujuran sebagai syarat sah perkawinan. Pemberian wajib ketika akan melangsungkan sebuah perkawinan dalam hukum Islam hanyalah mahar dan bukan jujuran. Sebagaimana yang telah disebutkan dalam firman Allah surah an-Nisa ayat 4 sebagai berikut:

Terjemahan: Berikanlah maskawin (mahar) kepada wanita (yang kamu nikahi) sebagai pemberian dengan penuh kerelaan. kemudian jika mereka menyerahkan kepada kamu sebagian dari maskawin itu dengan senang hati, Maka makanlah (ambillah) pemberian itu (sebagai makanan) yang sedap lagi baik akibatnya.

Pemberian itu ialah maskawin yang besar kecilnya ditetapkan atas persetujuan kedua pihak, karena pemberian itu harus dilakukan dengan ikhlas. Menurut informen AM dan SI, jumlah jujuran yang banyak tidaklah menjadi keharusan, melainkan kesukaarelaan, itulah yang diharuskan, tentunya siapa saja menginginkan kehidupannya dalam kecukupan dan bahagia. Kepercayaan ini sudah menyatu dengan begitu lekat dalam masyarakat, maka masyarakat akan mematuhi dan tidak akan meninggalkannya.

Ketika pihak laki-laki yang dimintai jujuran dengan jumlah yang cukup besar adalah berasal dari keluarga yang mampu, jujuran yang banyak tidaklah menjadi suatu masalah. Bahkan ada kebanggaan dan

12 Ibid 
kepuasan tersendiri bagi laki-laki yang sanggup membayar jujuran sesuai nominal yang diminta oleh pihak wanita tanpa harus tawar menawar, dengan begitu dapat menunjukkan pada keluarga wanita dan juga kepada masyarakat bahwa akan benar-benar bisa membahagiakan wanita bila telah menjadi istrinya kelak. Sebaliknya bila pihak laki-laki berasal dari keluarga yang paspas-an bahkan tidak mampu, maka jelaslah hal ini dapat membebani mereka. Secara keseluruhan jujuran merupakan hadiah yang diberikan calon mempelai laki-laki kepada calon istrinya sebagai keperluan pekawinan dan rumah tangga. Secara sepintas, istilah tersebut di atas memang memiliki pengertian dan makna yang sama, yaitu samasama merupakan kewajiban. Namun, jika dilihat dari sejarah yang melatarbelakanginya pengertian ketiga istilah tersebut jelas berbeda. Maskawin atau mahar adalah kewajiban dalam tradisi Islam, sedangkan jujuran adalah kewajiban menurut adat masyarakat setempat. Selain sebagai suatu ketentuan wajib dalam perkawinan, berdasarkan unsur-unsur yang ada di dalamnya dapat dikatakan bahwa jujuran mengandung tiga makna, pertama, dilihat dari kedudukannya jujuran merupakan rukun perkawinan di kalangan masyarakat desa Muara Sumpoi. Kedua, dari segi fungsinya jujuran merupakan pemberian hadiah bagi pihak mempelai wanita sebagai biaya resepsi perkawinan dan bekal dikehidupan kelak yang sudah berlaku secara turun temurun mengikuti adat istiadat. Ketiga, dari segi tujuannya pemberian jujuran adalah untuk memberikan prestise (kehormatan) bagi pihak keluarga perempuan jika jumlah jujuran yang dipatok mampu dipenuhi oleh calon mempelai pria. Kehormatan yang dimaksudakan disini adalah rasa penghargaan yang diberikan oleh pihak calon mempelai pria kepada wanita yang ingin dinikahinya dengan memberikan pesta yang megah untuk pernikahannya melalui jujuran tersebut.

Agama Islam sebagai agama yang penuh rahmat menerima adat dan budaya selama tidak bertentangan denga Syari'at Islam dan 
kebiasaan tersebut telah menjadi suatu ketentuan yang harus dilaksanakan dan dianggap sebagai aturan atau norma yang harus ditaati, maka adat tersebut dapat dijadikan pijakan sebagai suatu hukum Islam yang mengakui keefektifan adat istiadat dalam interpretasi hukum. Sebagaimana kaidah fiqhiyah:

Terjemahan : Adat kebiasaan dapat dijadikan pijakan hukum ${ }^{13}$

Di desa Muara Sumpoi pemberian jujuran diartikan sebagai pemberian wajib dalam perkawinan yang diberikan kepada mempelai wanita dari mempelai laki-laki selain uang mahar. Pemberian jujuran dalam perkawinan adat masyarakat desa Muara Sumpoi tidak dapat ditinggalkan dan sudah mendarah daging dalam diri masyarakat. Pemberian jujuran pada masyarakat Muara Sumpoi walaupun tidak diatur dalam hukum Islam, namun tradisi tersebut sudah menjadi suatu kewajiban yang harus ditunaikan demi kelancaran dalam perkawinan adat masyarakat desa Muara Sumpoi. Adat dan kebiasaan selalu berubah-ubah dan berbeda-beda sesuai dengan perubahan zaman dan keadaan.

Realitas yang ada dalam masyarakat berjalan terus menerus sesuai dengan kemaslahatan manusia karena berubahnya gejala sosial kemasyarakatan. Oleh karena itu, kemaslahatan manusia itu menjadi dasar setiap macam hukum. Maka sudah menjadi kewajaran apabila terjadi perubahan hukum karena disebabkan perubahan zaman dan keadaan serta pengaruh dari gejala kemasyarakatan itu sendiri. Sebagaimana kaidah fiqhiyah berikut: Artinya: "Tidak dapat dipungkiri bahwa berubahnya hukum, disebabkan berubahnya zaman". ${ }^{14}$

Walaupun pemberian jujuran tidak diatur dalam hukum Islam, namun pemberian jujuran sudah merupakan suatu tradisi yang harus dilakukan pada masyarakat desa Muara Sumpoi tersebut dan selama hal ini tidak

${ }^{13}$ Jaih Mubarok, Kaidah Fikih dan Kaidah Asasi, Jakarta:PT. Raja Grafindo Persada, 2002,

${ }^{14}$ Toha Andiko, ilmu Qawa 'id Fiqhiyyah, Yogyakarta: Teras, 2011, h. 157. 
bertentangan dengan akidah dan syari'at maka hal ini diperbolehkan. Dalam sebuah hadits| Nabi SAW bersabda:

Telah menceritakan kepada kami Abu Bakar telah menceritakan kami 'Ashim dari Zirr bin Hubaisy dari Abdullah bin Mas'ud berkata sesungguhnya allah melihat hati para hamba lalu dia mendapati hati Muhammad Shalla>llahu 'alaihi wasallam sebagai sebaikbaik hati para hamba, lalu memilihnya untuk dirinya,dia juga mengutusnya dengan risalah kemudia Dia melihat pada hati para hamba setelah hati Muhammad, maka Dia mendapati hati para sahabat sebagai sebaik-baik hati para hamba,lalu menjadikan mereka sebagai pembantu NabiNya, berperang membela agamanya. Maka apa yang dilihat oleh kaum muslimin satu kebaikan, maka disisi Allah adalah baik dan apa yang mereka pandang buruk, maka disisi Allah juga buruk. (HR. Ahmad, nomor hadis 3418) ${ }^{15}$

Pemberian jujuran di desa Muara Sumpoi merupakan suatu kewajiban yang harus dipenuhi dan biasanya dalam jumlah yang tidak sedikit. Namun demikian dari hasil wawancara diperoleh gambaran bahwa pria yang ingin menikahi wanita merasa terbebani dengan penentuan jujuran yang relatif tinggi, karena dalam penentuan jumlah jujuran itu terjadi proses tawar menawar terlebih dahulu sampai tercapai sebuah kesepakatan, sehingga masih dalam jangkauan kemampuan pihak laki-laki untuk memenuhi jujuran yang disyaratkan. Perbedaan tingkat sosial masyarakat sangat mempengaruhi terhadap nilai jujuran yang disyaratkan. Di antaranya adalah status ekonomi wanita yang akan dinikahi, kondisi fisik, jenjang pendidikan, dan pekerjaan. Cara responden dalam menyelesaikan problematika penentuan jujuran, mereka memberikan pemahaman terhadap para orang tua, bahwasannya jujuran bukanlah suatu keharusan akan tetapi merupakan pemberian yang sifatnya sukarela, Karena memang tidak ada ketentuan dalam agama yang mengatur bagaimana cara penentuan jujuran, mereka-pun berani memegang adat tentang masalah jujuran yang ditentukan tersebut, karena agama memang

\footnotetext{
${ }^{15}$ Imam Ahmad, Musnad Ahmad dalam kitab 9 imam (Software Ensklopedi Hadist) Jakarta : Lidwa Pusaka i-Software, 2009, h.137.
} 
menyerahkan masalah adat kepada masing-masing masyarakat, kebiasaan dan kesepakatan kedua pihak.

Mengenai masalah tersebut dalam sebuah hadis Rasullullah yaitu sebagai berikut dalam firman Allah, surat al-Baqarah ayat 185 :

Artinya: "...Allah menghendaki kemudahan bagimu dan tidak menghendaki kesulitan bagimu...”(QS. Al-baqarah :185).

Melihat dari makna hadis dan ayat tersebut di atas, maka sangat tidak etis jika jujuran yang diberikan oleh calon suami lebih banyak dari pada uang mahar. Dasar di atas sangat jelas menganjurkan kepada pihak wanita, agar meringankan pihak laki-laki dalam masalah penentuan jujuran yang tinggi, apalagi jujuran yang sama sekali tidak ada ketentuan wajib dalam hukum Islam. Agama Islam sebagai agama rahłmat $l i$ ' $a>l a m i>n$ tidak menyukai penentuan mahar yang memberatkan pihak lakilaki untuk melangsungkan perkawinan, demikian pula jujuran dianjurkan agar tidak memberatkan bagi pihak yang mempunyai niat suci untuk menikah. Perkawinan sebagai sunnah Nabi hendaknya dilakukan dengan penuh kesederhanaan dan tidak berlebih-lebihan sehingga tidak ada unsur pemborosan di dalamnya, karena Islam sangat menentang pemborosan. Sebagaimana yang telah disebutkan dalam firman Allah surah al-Isra>' ayat 27 sebagai berikut:

Terjemahan: "Sesungguhnya pemboros-pemboros itu adalah saudara- saudara syaitan dan syaitan itu adalah sangat ingkar kepada Tuhannya”. (Q.S Al-Isra' ; 27).

Hukum Islam dikenal prinsip mengutamakan kemudahan ( $r a f$ ' attaysir) dalam segala urusan. Terlebih lagi dalam hal perkawinan prinsip ini sangat ditekankan. Para wanita tidak diperkenankan meminta hal yang justru memberatkan pihak laki-laki karena hal ini mempunyai beberapa dampak negatif, diantaranya: ${ }^{16}$ Menjadi hambatan ketika akan melangsungkan perkawinan terutama bagi mereka yang sudah serius dan

${ }^{16}$ Sulaiman Rasjid, Fiqh Islam, Jakarta: Attahriyah, 1954, h 373 
saling mencintai. Mendorong dan memaksa laki-laki untuk berhutang demi mendapatkan uang yang disyaratkan oleh pihak wanita. Mendorong terjadinya kawin lari dan terjadinya hubungan diluar nikah.

Agama Islam tidak membeda-bedakan status sosial dan kondisi seseorang apakah kaya, miskin, cantik, jelek, berpendidikan atau tidak. Semua manusia dihadapan Allah mempunyai derajat dan kedudukan yang sama, hal yang membedakan hanyalah takwa. Sebagaimana yang telah dijelaskan dalam firman Allah surah al-Hujurat ayat 13:

Hai manusia, Sesungguhnya Kami menciptakan kamu dari seorang laki-laki dan seorang perempuan dan menjadikan kamu berbangsa bangsa dan bersuku-suku supaya kamu saling kenal- mengenal. Sesungguhnya orang yang paling mulia diantara kamu disisi Allah ialah orang yang paling taqwa diantara kamu. Sesungguhnya Allah Maha mengetahui lagi Maha Mengenal. (Q.S al-H\{ujura>t :13).

Dengan demikain cara yang dilakukan pihak calon pasangan dalam menyelesaikan problematika penentuan jujuran dibenarkan, yaitu memberikan pengertian keagamaan yang berkaitan dengan adat jujuran, di mana jujuran bukan suatu keharusan akan tetapi suatu pemberian yang bersifat suka rela. Karena tradisi pemberian jujuran juga sesuai dengan asas hukum perkawinan Islam, didalamnya terdapat asas kerelaan dan kesepakatan antara pihak mempelai laki-laki dan pihak mempelai perempuan dalam penentuan nilai jujuran.

\section{E. Kesimpulan}

Dari uraian dan pembahasan yang telah dikemukakan pada bab terdahulu maka hasil penelitian ini dapat disimpulkan sebagai berikut: Problematika penentuan jujuran di Desa Muara Sumpoi dengan segala ketentuan yang berlaku di dalamnya disebabkan adanya faktor-faktor yang mempengaruhinya, dan faktor ekonomilah yang lebih dominan selain adanya pengaruh dari faktor-faktor lainnya seperti masalah pendidikan, acara walimah, kecantikan, serta kebutuhan mereka nantinya. 
Cara yang dilakukan pihak calon pasangan dalam menyelesaikan problematika penentuan jujuran, yaitu memberikan pengertian keagamaan yang berkaitan dengan adat jujuran, di mana jujuran bukan suatu keharusan akan tetapi suatu pemberian yang bersifat suka rela, meskipun cara tersebut masih belum berhasil menyatukan hubungan mereka yang mempunyai masalah penentuan jujuran. Menurut pandangan Hukum Islam jujuran harus berupa sesuatu yang tidak bertentangan dari syari'at Islam, Karena memang tidak ada ketentuan dalam agama yang mengatur bagaimana cara penentuan jujuran. sehingga cara yang dilakukan pihak calon pasangan dalam menyelesaikan problematika penentuan jujuran, yaitu dengan memberikan pengertian keagamaan yang berkaitan dengan adat jujuran, telah sesuai dengan ajaran Hukum Islam.

\section{Daftar Pustaka}

Amir Mu'allim dan Yusdani, Konfigurasi Pemikiran Hukum Islam, Yogyakarta: UII Press Indonesia, 2001.

As'ad, Mujib, Kaidah - Kaidah Imu Fiqih, Jakarta: Kalam Mulia, 1999.

Daud, Alfani, Islam dan Masyarakat Banjar, Jakarta: PT. Raja Grafindo Persada, 1997.

Departemen Agama RI, Al-Qur'an dan Terjemahnya, Surabaya: Mekar, 2002.

Djazuli, A., Kaidah-kaidah Hukum Islam dalam Menyelesaikan Masalah-Masalah yang Praktis, Jakarta: PT. RajaGrafindo Persada, 2000.,dan Nurul Aen, Ushul Figh Metodologi Hukum Islam, Jakarta: Raja Grafindo Persada, 2000.

Ghozali, Abdul Rahman Fiqh Munakahat, Jakarta: Kencana, 2008. Kaelany, Aspek-aspek kemasyarakatan, Jakarta: Bumi Aksara, 2000.

Khalaf, Abdul Wahhab, Kaidah-kaidah Hukum Islam (Ilmu Ushulul Fiqh),Jakarta: Raja Grafindo Persada, 2002. ,Ilmu Ushul Fiqih, Penterjemah Moh. Zuhri dan Ahmad Qarib, Semarang: Dina Utama, 1994.

Milles dan Huberman, Analisis Data Kualitatif, Jakarta: UIP, 1992. 
Moleong, Lexi J., Metodologi Penelitian Kualitatif, Bandung: PT. Remaja Rosdakarya, 2001

Rasjid, Sulaiman, Fiqh Islam, Jakarta: Attahriyah, 1954.

Sabiq, Sayyid, Fikih Sunnah, jilid 7, Penerjemah Mahyuddin Syaf, Bandung: Al- Ma'arif, 1978.

Soemitro, Ronny Hanitijo, metodologi Penelitian Hukum dan Jurimetri, Jakarta: Ghalia Indonesia, 1990.

Sya'rawi, Muhammad Mutawwali, Fiqih Wanita; Mengupas Keseharian Wanita dari Masalah Klasik Hingga Kontemporer, Penerjemah Ghozi M, Jakarta: Pena Pundi Aksara

Tim MQS Publishing, Jendela Keluarga, Bandung: MQS Publisihing, 2004, h. 103.

Tim Penyusun Almanar, Fikih Nikah, Bandung: Syaamil Cipta Media, 2003.

Tim Penyusun Kamus Pusat Pembinaan dan Pengembangan Bahasa, Kamus Besar Bahasa Indonesia, Jakarta: Balai Pustaka, 2005.

Tim Penyusun, Pedoman Penulisan Skripsi Sekolah Tinggi Agama Islam Negeri (STAIN), Palangka Raya: 2007.

Totok Jumantoro dan Samsul Munir Amin, Kamus Ilmu Ushul Fikih, t.tp: AMZAH, 2005.

Uman, Khairul dkk, Ushul Fiqh 1, Bandung: Pustaka Setia, 2002.

Utsman, Sabian, Dasar-dasar Sosiologi Hukum, Yogyakarta: Pustaka Pelajar, 2009.

Usman, Muchlis, Kaidah-kaidahUshuliyah dan Fiqhiyah, Jakarta: Raja Grafindo Persada, 1999.

Najmi, Nurin, Persepsi Masyarakat Banjar Terhadap Mahar dan Jujuran dalam Perkawinan di Kecamatan Martapura Kabupaten Banjar Kalimantan Selatan (Studi Terhadap 10 orang warga Martapura), (skripsi). Palangka Raya STAIN, t.np, 2003.

Ahmad Harris Aldhaniar, "Mahar dalam Masyarakat Bugis di Ballekahu Bone", 2008, dalam http://lib.uin$\underline{\text { malang.ac.id/?mod=th_detail } \& i d=04210043}$. 
Bahrul Munib, Korelasi Mata Pencaharian dengan Mahar pada Masyarakat Sutojayan Blitar” 2007, dalam http://lib.uinmalang.ac.id/?mod=th_detail\&id=00210074.

Budaya Indonesia yang Beragam," dalam http://www.bimbingan.org/budaya-indonesia- yang-beragam.htm,

Dina Aprilia, “Budaya Jujuran dalam Perkawinan Adat Banjar', 2007, dalam http://digilib.umm.ac.id/files/disk1/173/jiptummpp-gdl-s1-2007dinaaprili-8636-1.+PENDA-N.pdf.

Gatot susanto, "Konsep pemberian pelaku (mahar) dalam adat perkawinan di desa Pangkalan Dewa kabupaten Kotawaringin Barat Kalimantan Tengah (perspektif hukum Islam)" 2010, dalam http://digilib.uinsuka.ac.id/4305/1/BAB\%20I,V,\%20DAFTAR\%20PUSTAKA.pdf.

http://aiysayyidhan.blogspot.com/2012/11/prosesi-pernikah-adat-dayakbakumpai -di.html, http://dayakofborneo.blogspot.com/2013/05/pernikahan-adat-dayakngaju-bakumpai.html, http://id.wikipedia.org/wiki/Suku_Dayak_Bakumpai,

Jujuran”, dalam $\quad$ http://bjn.wikipedia.org/wiki/Jujuran. Khairil Muslim, "Tradisi Jujuran", http://khairilmuslim.wordpress.com/2011/03/15/tradisi-jujuran/.

Nik Ahmad Othman B. Mohammad Zahid, "Faktor-faktor Peningkatan Kadar Mahar dalam Perkawinan (Studi Kasus dalam Masyarakat Kota Bharu, Kelantan Malaysia)", dalam http://sasarraniry.files.wordpress.com/2010/12/2011- faktor-faktorpeningkatan-kadar-mahar-dalam-perkawinan.pdf.

Oktavina Qurrota Ayun, "Bicara Jujuran”, dalam https://indonesiamengajar.org/cerita- pm/oktavina-ayun/bicara-jujuran.

Rizka Yeni A, "Transplantasi Organ Tubuh Sebagai Mahar Nikah" 2011

http://lib.uin-malang.ac.id/?mod=th_detail\&id=05210003, (Online 18 Juni 2013). Salim Suharis, "Jujuran, Budaya Pernikahan Yang Kurang Islami”, dalam

http//salim suhari-jujuran-budaya-islam.net. Ukhti Raida, "Jujuran", dalam http://galericerpen-flp.blogspot.com/2011/02/jujuran.html. 
Yanu Irdianto Priandana, "Pengertian Kebudayaan,Unsur-Unsur Kebudayaan,Wujud Kebudayaan dan Perubahan Kebudayaan" dalam http://yanuirdianto.wordpress.com/2013/03/10/96/

Imam Ahmad, Musnad Ahmad dalam kitab 9 imam (Software Ensklopedi Hadist) Jakarta : Lidwa Pusaka i-Software, 2009. 